\title{
STRONGER TOGETHER? THE USW-MONDRAGON UNION CO-OP MODEL
}

\author{
Laura Hanson Schlachter \\ Department of Sociology \\ University of Wisconsin-Madison \\ 8128 Sewell Social Sciences Building \\ 1180 Observatory Drive \\ Madison, WI 53706 \\ 608-262-9588 (phone) \\ 608-265-5389 (fax) \\ 1hanson4@wisc.edu
}

September 2016

Laura Hanson Schlachter is a $\mathrm{PhD}$ student in the University of Wisconsin-Madison Department of Sociology. She has a Master in Public Affairs from the Woodrow Wilson School at Princeton University and seven years of professional experience working with cooperatives.

The author thanks Erik Wright, Jane Collins, Robert Freeland, Ariana Levinson, Elizabeth Hoffmann, anonymous reviewers, and participants in the University of Wisconsin-Madison Economic Sociology Brown Bag for thoughtful comments. The Rutgers School of Management and Labor Relations supported this work through a 2015-16 Beyster Research Fellowship. The author is deeply grateful to the individuals in Cincinnati who so generously shared their insight and inspiration. All views and errors are solely those of the author. 


\begin{abstract}
In 2009, United Steelworkers (USW) and Mondragon signed an agreement to promote union coops: firms that combine democratic worker ownership and union membership. Eleven U.S. initiatives now seek to implement the USW-Mondragon union co-op model, prompting a debate about whether unions and worker cooperatives are stronger together. This article draws on a case study of the first such initiative in Cincinnati, Ohio to put claims about the model in dialogue with aspirations and experiences of people on the ground. I synthesize six possibilities and dilemmas of union involvement in worker cooperative formation and argue that these considerations should structure the future debate.
\end{abstract}

\title{
Keywords
}

Union, Cooperative, Union Co-op, Worker Ownership, Mondragon

\section{Introduction}

"A worker cooperative directly connected to the labor movement is $[\ldots]$ the most beautiful version of democracy in the economy that I can imagine," said Casey WhittenAmadon, Apple Street Market Project Manager at the Cincinnati Union Co-op Initiative. Like increasing numbers of workers across the United States, Whitten-Amadon embraced cooperatives - businesses owned and democratically governed by members according to the principle of one member, one vote - as a solution to economic insecurity. He was also part of a growing group of labor activists calling for unions to support worker cooperative development as an alternative to traditional workplace organizing.

Union interest in worker cooperatives has grown dramatically since the United Steelworkers Union (USW) and Mondragon federation of worker cooperatives in Spain signed a collaboration agreement in 2009. The agreement claims that unionization is a strategy to scale 
up the worker cooperative sector in North America (USW and MCC 2009). In 2012, they released a formal model for union co-ops that combine elements of democratic worker ownership and union membership (Witherell, Cooper, and Peck 2012). At least eleven initiatives across the U.S. are now attempting to establish union co-ops explicitly patterned after the USWMondragon model. These initiatives directly engage unions in worker cooperative formation in hopes that unionization will help overcome challenges during the startup process. The first effort to emerge was the Cincinnati Union Co-op Initiative (CUCI), a nonprofit that has incubated three union co-ops in Cincinnati, Ohio since 2011.

This article draws on a case study of CUCI to put claims about the USW-Mondragon union co-op model in dialogue with aspirations and experiences of the first people attempting to implement it on the ground. Given that worker cooperatives offer higher employment stability, solidarity, opportunities for wealth accumulation, and other benefits relative to conventional firms, researchers have puzzled over their marginality in the U.S. economy (Hoffmann 2006a, Gordon Nembhard and Blasingame 2006, Wright 2010). In 2013, the United States was home to fewer than three hundred worker cooperatives with an average size of eleven workers per firm (Palmer 2015). Previous studies posit low formation rates as a key constraint (Olsen 2013) in addition to cultural individualism (Corcoran and Wilson 2010), lack of financing (Gintis 1998), and degeneration of democratic decision-making structures (Hansmann 1996). Advocates of the USW-Mondragon model claim that union involvement in the establishment and growth of worker cooperatives will help mitigate these constraints. Detractors claim it will simply exacerbate them.

Although current evidence from existing USW-Mondragon initiatives is too limited to adjudicate whether unions and worker cooperatives are in fact stronger together, I seek to 
intervene by offering a set of theoretically and empirically informed considerations to guide the debate going forward. CUCI case study data includes twenty in-depth interviews, participant observation, organizational documents, and media coverage from 2013 to 2016 . I synthesize my findings about CUCI's implementation of the USW-Mondragon model in Cincinnati with an interdisciplinary literature about the relationship between worker cooperatives and the labor movement to propose six possibilities and dilemmas of the USW-Mondragon model for worker cooperative formation in the U.S. These possibilities include the potential for unions to bring valuable resources to bear in the startup process, facilitate conflict resolution within firms, and link cooperatives with working class struggles. Dilemmas include the potential for unionization to foster divisions between cooperative workers and owners, introduce conflicts of interest for union-affiliated management, and perpetuate discriminatory practices. I argue that scholars should investigate these questions in future research as USW-Mondragon initiatives continue to mature. Unions and workers should also take these considerations into account as they contemplate adapting the model to their own context.

\section{Literature Review: Potential and Pitfalls of Worker Cooperatives}

Interest in democratic worker ownership as an alternative or compliment to workplace organizing has historically grown during periods of economic uncertainty and social unrest. ${ }^{1}$ The first wave of worker cooperative formation in the U.S. coincided with the boom-and-bust years of the $19^{\text {th }}$ century as the early labor movement explored strategies to challenge the wage labor system. The second wave took place during the 1970s as activists sought to establish economic organizations that embodied their countercultural values. The third wave emerged in the wake of the Great Recession and unprecedented levels of inequality. Almost one-third of

\footnotetext{
${ }^{1}$ Unemployment rates and worker cooperative formation are not significantly associated in statistical terms but have historically coincided with business cycle downturns (Bonin, Jones, and Putterman 1993).
} 
contemporary U.S. worker cooperatives formed after 2010 (Palmer 2015). Cities like New York and Madison have dedicated a total of over $\$ 8.5$ million to worker cooperative development since 2013 (DAWI 2016, Schlachter 2016). Democratic presidential candidate Bernie Sanders even featured worker cooperatives in his platform, citing the Mondragon federation of 110 worker cooperatives in Spain as an exemplar of economic self-determination (Jilani 2015). Emancipatory Aspirations

Activists have often held up worker cooperatives as models for a "new" (NEC 2015), "generative" (Kelly 2012), and "solidarity" (Loh and Shear 2015) economy. A growing interdisciplinary literature documents their benefits in the workplace and beyond. For example, worker loyalty and cooperative values of democracy and equity are especially pronounced in democratic worker-owned firms (Malleson 2014, Hoffmann 2006b). ${ }^{2}$ Overall, worker cooperatives have more equal internal wage structures and higher employment stability than conventional counterparts (Olsen 2013, Bonin, Jones, and Putterman 1993). They can also promote wealth accumulation for marginalized groups and yield positive spillover effects in civic participation and social capital (Majee and Hoyt 2010, Gordon Nembhard 2014). Studies of Mondragon and the Emilia Romagna cooperatives in Italy suggest that associational networks help realize these benefits by incubating, financing, and sustaining individual firms as well as facilitating inter-cooperation in ways that privilege the interests of workers over those of capital (Greenberg 1986, Wright 2010). For example, after Mondragon's Fagor cooperative went bankrupt in 2013, the federation helped at least 600 displaced worker-owners retire early or relocate to jobs in other cooperatives (Navarro 2014).

\footnotetext{
${ }^{2}$ The International Cooperative Alliance (ICA) is the global association for cooperatives that stewards the definition of cooperatives and their values and principles. The seven ICA principles include: 1) voluntary and open membership; 2) democratic member control; 3) member economic participation; 4) autonomy and independence; 5) education, training and information; 6) co-operation among co-operatives; 7) concern for community (ICA 2012).
} 
Erik Olin Wright terms these types of associational networks "cooperative market economies." Unlike an isolated worker cooperative in a capitalist market, a cooperative market economy "constitutes a social infrastructure for the reproduction and expansion of cooperative ownership which partially insulates each cooperative firm from the full force of the competitive, profit-maximizing pressures of capitalist markets" $(2010,241)$. Rather than simply carving out their own emancipatory niche, Wright argues, firms in a cooperative market economy have the potential to erode capitalism by introducing more egalitarian, democratic, and ecologically sustainable values into economic practice (2012). Recent Mondragon-inspired efforts to seed cooperative market economies in the U.S. both promote the visibility of worker cooperatives and encounter many of the challenges that limit their formation and growth.

\section{Constraints}

Skeptics often cite the extreme rarity of worker cooperatives as evidence that democratic worker ownership is not viable or perhaps even desirable in the United States. In 2013, the entire country had only 256 worker cooperatives that collectively employed an estimated 6,500 individuals, almost one-third of whom work at Cooperative Home Care Associates in New York City (Palmer 2015). Worker cooperatives are also rare in comparison to producer, purchasing, and consumer cooperatives, representing less than one percent of the sector (Deller et al. 2009). Given their small scale in terms of number of firms and workers per firm, worker cooperatives have yet to create a cooperative market economy in the U.S.

Scholars typically explain the marginality of U.S. worker cooperatives in terms of four constraints. First, low formation rates appear to inhibit sector growth. Citing evidence that European worker cooperatives have higher survival rates than comparable conventional firms, Erik Olsen (2013) suggests that entrepreneurs rarely form worker cooperatives because they are 
unfamiliar with the business model and unlikely to extract entrepreneurial rents from a collectively owned enterprise. Second, worker cooperatives typically face higher capital costs than conventional counterparts due to widespread unfamiliarity with the cooperative business model, worker equity underinvestment, and limits to external investor control over business decisions (Olsen 2013, Gintis 1998, Bonin, Jones, and Putterman 1993). Inadequate financing is often particularly acute during the startup phase. Third, cultural analyses of Mondragon and Emilia Romagna attribute their success to traditions of collectivism and solidarity - the willingness to engage in collective sacrifice - that are particularly strong in the Basque region of Spain and Northern Italy (Putnam 1993, Corcoran and Wilson 2010). By extension, cultural individualism makes the U.S. less conducive to the worker cooperatives and other solidaristic civic institutions that make up thriving cooperative market economies. ${ }^{3}$ The fourth constraint is that worker cooperatives may face inherent limits to growth because transaction costs become unwieldy as they increase in size and complexity, imposing tradeoffs between efficiency and values (Hansmann 1996). Furthermore, equity shares in profitable cooperatives can become so valuable that new workers are unable to buy in (Bartlett et al. 1992).

Researchers have yet to systematically compare formation rates of U.S. worker cooperatives and conventional counterparts. Nor have they disentangled the relative impacts of entrepreneurial incentives, financing, culture, and governance. Nevertheless, the hypothesis that the startup process itself is the largest barrier to sector growth is gaining traction among activists; proposals for strategies to boost formation rates have proliferated in recent years (Abell 2014, Michael 2015). One proposal in particular - direct union involvement in the worker cooperative development process - attracted the attention of USW leaders seeking creative solutions to

\footnotetext{
${ }^{3}$ Cultural explanations of worker cooperative emergence often point out that the concentration of cooperatives in the U.S. appears to be spatially correlated with settlement patterns of Scandinavian and German migrants who have strong traditions of egalitarianism and communalism (see Schneiberg 2011).
} 
membership decline. They brokered the 2009 collaboration agreement with Mondragon, calling for the creation of new industrial union jobs through the formation of unionized worker cooperatives in North America (USW and MCC 2009). The 2012 USW-Mondragon union co-op template takes this appeal one step further by elaborating a formal model for developing a new generation of unionized worker cooperatives in the U.S. (Witherell, Cooper, and Peck 2012).

Previous scholarship provides an empirical foothold to explore the idea that overcoming constraints to worker cooperative formation could make benefits such as higher employment stability, wealth accumulation, and egalitarian pay structures accessible to much larger numbers of U.S. workers. It offers few definitive answers, however, to the question of whether unionization is a pathway to a cooperative market economy. How do people forming new USWMondragon union co-ops articulate their aspirations and interpret their early experiences? My goal is to put their accounts in dialogue with advocates' and detractors' claims about the model in order to provide some theoretical coherence to the debate. The next section contextualizes the USW-Mondragon model's emergence and institutional design. I then delve into a case study of CUCI and synthesize key possibilities and dilemmas of the model. I argue that these considerations should guide both future union co-op research and development practice.

\section{Overview of the USW-Mondragon Model}

In March 2012, USW and Mondragon hosted a press conference with the Ohio Employee Ownership Center (OEOC) to introduce their jointly crafted union co-op model (USW 2013). It aims to promote worker ownership, collective organization, democracy, and solidarity within labor by formally incorporating union membership into the institutional design of a worker cooperative (Witherell, Cooper, and Peck 2012). While retaining many features of a Mondragon cooperative, the model replaces Mondragon's social council with a union committee. Worker 
cooperatives in the Mondragon federation espouse ten principles ${ }^{4}$ and establish three internal bodies: the general assembly of all worker-owners, an elected board of directors, and management. Mondragon also encourages large worker cooperatives to establish a fourth internal body called a social council that focuses explicitly on issues affecting worker well being such as wages, working hours, and fringe benefits. Social councils differ from boards of directors because they have advising rather than governance power and representatives are elected proportionally from each worker category (salespeople, electricians, etc.) instead of at large from the general assembly. They also differ from unions because they cannot call strikes. Mondragon maintains that unionization is unnecessary in the Basque context where unions are historically highly politicized and cultural norms of solidarity make it possible to resolve contentious issues without external intervention (Whyte and Whyte 1991). Establishing a social council is strongly encouraged in Mondragon cooperatives with more than 50 worker-owners and mandatory in those with more than 100 (Fernandez de Landa 2013).

The USW-Mondragon model mimics the institutional design of Mondragon cooperatives but replaces social councils with analogous union committees. Union members elect committee representatives who are responsible for facilitating communication regarding issues that affect worker well being. Unlike a social council, however, the union committee is empowered to negotiate a legally binding collective bargaining agreement (CBA) with management regarding guidelines for wages, benefits, grievance processes, and other relevant issues. The CBA covers all workers in the collective bargaining unit including non-owners and temporary employees. ${ }^{5}$

\footnotetext{
${ }^{4}$ Mondragon principles: 1) open admission, 2) democratic organization by one worker, one vote, 3) sovereignty of labor, 4) instrumental and subordinate nature of capital, 5) participation in management, 6) wage solidarity, 7) inter-cooperation, 8) social transformation, 9) universality, and 10) education.

${ }^{5}$ In this article, I differentiate between four types of workers in a union co-op. Worker-owners are both cooperative owners and union members. People on track to worker ownership are union member who
} 
Inspired by the model's claim that it represents a "path towards creating good, sustainable jobs that support and sustain the communities in which they operate" (Witherell, Cooper, and Peck 2012, 6), activists have established at least eleven initiatives to develop USW-Mondragon union co-ops since 2011. They have affiliated under the umbrella of a nonprofit dedicated to seeding new union co-ops across the U.S. called Mondragon USA.

Table I: Union Co-op Initiatives in the Mondragon USA Network, August 2016

The U.S. is also home to at least nine union co-ops that unionized after the worker cooperative was established (UCC 2016). The most prominent is Cooperative Home Care Associates, which joined SEIU 1199 eighteen years after founding to raise the sector wage floor and expand worker participation (Berry and Schneider 2011). Although these cases offer hopeful examples for empowering workers, they offer limited opportunities to explore the implications of direct union involvement in the worker cooperative formation process. For this reason, I differentiate between unionized worker cooperatives in general and the subset of initiatives that are explicitly attempting to emulate the USW-Mondragon model and engage unions in the formation process.

\section{Table II: Worker Cooperative Typology}

The earliest adopter of the USW-Mondragon model was the Cincinnati Union Co-op Initiative (CUCI), a nonprofit union co-op incubator launched in 2011. CUCI has established three firms that have created 25 new jobs to date. Given that half of new U.S. firms fail within the first five years and the average startup employs only five people at founding (Reedy and Litan 2011, BLS 2014a), many union co-op advocates have hailed CUCI's early achievements as a sign that direct union involvement has the potential to improve rates of worker cooperative formation and job growth (Sherlock 2014, Hoyer 2015, Dean 2013, Witherell 2013). CUCI is the first and most 
mature initiative to develop union co-ops explicitly patterned after the USW-Mondragon model and a suggestive case for thinking about its implications.

\section{Data and Methods}

My qualitative case study of CUCI draws on twenty semi-structured interviews I conducted from July 2014 to November 2015 with a stratified purposive sample of key informants. Each interviewee had significant experience developing union co-ops through CUCI or working in its affiliated startups. In order to include different perspectives based on role, demographic characteristics, and union biography, I invited specific individuals to participate. I also interviewed a peripheral sample of individuals involved with other cooperative development efforts in Cincinnati. In total I interviewed five founders, ten board directors, five nonprofit and cooperative workers, six women, fourteen men, sixteen Whites, three African-Americans, and one Latino. All interviewees granted permission to be directly quoted using their real names.

I triangulated my thematic analysis of interview transcripts with participant observation during organizational events and meetings, a review of organizational documents and media coverage, and interviews with three CUCI founders conducted by Ariana Levinson. She generously shared these transcripts with permission from the institutional review boards of the University of Wisconsin-Madison and University of Louisville as well as each interviewee. I used them for triangulation purposes only; all quotes are from interviews I personally conducted.

\section{Case Study: The Cincinnati Union Co-op Initiative}

Cincinnati is a Rust Belt city that has been hard hit by industrial decline. Although still home to large corporations like Procter \& Gamble, the city lost several major employers during the 1980-90s. Manufacturing now represents only 15 percent of local GDP (Brookings Institute 2014). In 2014, Cincinnati had 115,500 unionized workers and a union density of 12.4 percent, 
slightly below the state average (Hirsch and Macpherson 2014, BLS 2014b). Cincinnati has also grappled with extreme levels of poverty and racial segregation. One in three adults and more than half of all children live in poverty, and the city has the nation's fourteenth highest black/white dissimilarity index (CensusScope 2015, Curnutte 2013).

\section{The CUCI Story}

In the midst of these challenges, the Intercommunity Justice and Peace Center (IJPC) began to explore new strategies to promote economic justice. It began sending delegations of civic leaders to visit Mondragon in the 1980s, including former Building Trade Unions leader Jerry Monahan. Upon his return in 1989, Monahan took his friend Phil Amadon aside at a Labor Council meeting and shared the idea of establishing a similar network of cooperatives in Cincinnati. Years later, Amadon cited that conversation as the inspiration for founding CUCI. Amadon had dedicated his 32-year career as a railroad mechanic to studying and promoting the labor movement. In 2009, he decided to bring together several organizer friends to study the history of union and worker cooperative collaboration. Kristen Barker was a staff member at the IJPC with strong connections to social justice nonprofits. Ellen Vera was a Field Organizer with United Food and Commercial Workers (UFCW) Local 75. Flequer Vera was an organizer with AMOS, a PICO-affiliated network of faith-based organizations working on immigrant rights campaigns. With their shared experiences in organizing and social justice, the group was intrigued by Mondragon's success in reducing inequality, empowering workers, and stimulating regional economic growth. They formed the Cincinnati Union Mondragon Study Group and met regularly throughout 2010 to read Making Mondragon (Whyte and Whyte 1991) and discuss strategies to enhance solidarity between unions and cooperatives. Like William Whyte, they saw unions as analogous to Mondragon social councils and concluded that union 
committees could "play a constructive role in representing workers' interests and balancing them against ownership interests" (Ibid, 275).

In 2011, the four founders decided to launch their own nonprofit union co-op incubator in Cincinnati. They hosted the first public CUCI event in February 2011, attracting more than 80 community members. Out of this group formed volunteer organizing committees that began to explore business ideas and reach out to potential union partners. In April, volunteers attended an OEOC workshop and met Michael Peck, Mondragon's North American Delegate, who soon became a vocal champion for CUCI. Over the next six months, CUCI filed incorporation papers and established a board of directors. The new nonprofit's mission was to develop union co-ops that "provide family-sustaining jobs and create an economy that works for all" (CUCI 2014). Incubating Union Co-ops in Cincinnati

CUCI is intimately involved in every aspect of establishing a new union co-op. During the incubation period, workers who are 'on track to worker ownership' undergo a one-year training process with weekly sessions structured around a formal curriculum. Meanwhile, a CUCI-appointed board of directors governs the cooperative and appoints management. Only after completing this training are workers eligible to invest their $\$ 3,000$ equity share and apply for worker-owner status. CUCI union co-ops leave the incubation period when a critical mass of worker-owners calls an inaugural general assembly. After a union co-op concludes the incubation period, at least one cooperative board seat remains reserved for a representative appointed by CUCI. Unions are also directly involved in the formation process in a variety of ways I will elaborate in the discussion of possibilities and dilemmas below. All workers except those with the power to hire and fire must join the cooperative's union after a 30-60 day probation period, which means that most employees are covered by a CBA and develop 
relationships with their union organizer regardless of ownership status. All union members are eligible to vote for the union committee, which negotiates the CBA with management. Although CUCI was exploring several business ideas at the time of this writing, it primarily focused on developing three union co-ops: Our Harvest, Sustainergy, and Apple Street Market. Table III: CUCI Union Co-ops, August 2016

CUCI's first goal was to convince Mondragon to establish a manufacturing subsidiary in Cincinnati that could partner with USW. They pitched the idea to Mondragon's Danobat Group Railway Division in July 2011 and arranged for Danobat representatives to meet with city officials in March 2012. Although CUCI piqued Mondragon's interest in establishing a subsidiary in the U.S., in 2014 Danobat opted not to locate in Cincinnati.

Next, CUCI decided to launch a food-related business that could partner with UFCW. Founders settled on the idea of an urban farm and food hub: a business that aggregates, distributes, and markets locally produced food to wholesalers, retailers, and institutions. The Our Harvest vision is to build an aggregation and distribution facility that eventually employs hundreds of worker-owners and increases community access to locally produced food. The union co-op launched with three farmers and six people on track to worker ownership in April 2012, renting land from an established urban farmer and distributing produce through farmers markets and a community supported agriculture program. From February 2013 to December 2014, UFCW Local 75 subsidized labor costs by allowing Ellen Vera to manage the formation process as Lead Organizer for the cooperative. In the summer of 2014, workers unanimously voted to join UFCW Local 75 and accept the CBA the union had drafted with the incubation board of directors. The union co-op survived a severe cash flow shortage during the 2014 season that forced it to renegotiate the terms of its startup loan from CoBank. In 2015, however, Our 
Harvest secured several institutional contracts and new management that implemented more efficient farming and administrative practices. At the time of this writing, Our Harvest was solvent and had grown to eighteen employees and four worker-owners.

CUCI's third business was an energy retrofitting union co-op that could partner with the IBEW and Pipefitters. Sustainergy's original vision was to leverage Property Assessed Clean Energy (PACE) financing to conduct energy audits and finance efficiency upgrades for commercial building owners. Flequer Vera led a team of volunteers to develop the business plan, seek financing, and partner with unions to successfully lobby the Cincinnati City Council to pass PACE legislation in March 2013. Sustainergy launched in November 2013 with a focus on commercial retrofits. In early 2015 , however, the incubation board decided to rewrite the business plan after they were unable to secure sufficient financing to compete in the commercial market. Instead they decided to pursue an opportunity with Empower Energy to conduct residential energy retrofits and help Cincinnati's utility meet its mandated efficiency goals. Sustainergy re-launched in March with this new focus and a partnership with the International Association of Heat and Frost Insulators and Allied Workers (Insulators) Local 8. In 2015, the union co-op secured a startup loan from Shared Capital Cooperative and began hiring. As of August 2016, Sustainergy had four employees, one worker-owner, and a growing clientele.

CUCI's most recent business idea, Apple Street Market, came to them. In September 2013, a group of residents in Cincinnati's Northside neighborhood approached CUCI and asked them to establish a retail grocery in an abandoned Save-A-Lot. The neighborhood council's attempts to attract a corporate grocer had been unsuccessful and the area now qualified as a food desert. In 2014, CUCI conducted a community survey, feasibility, and market studies and recruited a project manager. Apple Street Market incorporated that May with a vision to 
establish a multi-stakeholder (worker- and consumer-owned) union co-op to provide fresh food and family-sustaining jobs in partnership with UFCW Local 75. In 2015, it hired a general manager with professional grocery experience, launched a consumer-owner drive, and secured low-cost loans from community development financial institutions. Despite ballooning construction costs that required pushing back opening until early 2017, Apple Street Market continued to gain community support and funding commitments to make up the difference. In August 2016, it had one employee, 1,129 consumer-owners, and plans to open in early 2017.

CUCI also supports USW-Mondragon initiatives in other cities by hosting visitors, sharing resources, and evangelizing the USW-Mondragon model at events like the 2015 AFLCIO national convention. Barker works as an organizer with Mondragon USA and both Barker and Vera serve on the board of Mondragon USA's foundation arm, 1Worker1Vote.

\section{Stronger Together? Six Possibilities and Dilemmas for Union Co-ops}

Growing interest in union co-ops has prompted intense scrutiny of CUCI's early efforts from scholars and practitioners alike. Treating CUCI as a litmus test for the USW-Mondragon union co-op model, however, is premature. Instead, I draw on the literature about constraints to worker cooperative formation to select the most relevant signals in a noisy debate about whether unions and worker cooperatives can be stronger together (Silver 2012). The discussion below puts accounts of CUCI informants in dialogue with claims about the USW-Mondragon model.

\section{Possibilities: Resources, Conflict Resolution, and Links to the Workers' Movement}

The first possibility is for unions to address key barriers to scale for worker cooperatives by bringing their financial, educational, political, and other resources to bear in the formation process. Unions remain one of the most important civic institutions in the U.S. despite significant declines since the 1970s, representing 14.5 million workers in 2013 (BLS 2015). 
Advocates of the USW-Mondragon template point out that union reserves are vastly larger than existing sources of patient capital for worker cooperative development. They claim that union co-ops could access loans through pension funds that prioritize investments in new businesses to create union jobs (Witherell 2013). They also cite union membership as a strategy to access more affordable benefits for worker-owners - costs that are often prohibitively expensive for small and startup firms (Witherell, Cooper, and Peck 2012).

At CUCI, over $\$ 23,000$ in financial contributions from USW, UFCW, the AFL-CIO, and the Building Trades Unions helped subsidize early business planning. Some interviewees expressed frustration, however, that aspirations to establish a union pension fund investment vehicle have yet to materialize. Unions have also been unwilling or unable to invest in start-ups directly: "I've not been feeling [...] that the unions have stepped up to the plate as much as they should," said CUCI board member Don Barker. "[USW] got all the press on this agreement with Mondragon but I think it's just lip service." Others held that unions are justifiably reluctant to invest member dues in risky startups. As Ellen Vera said:

I think sometimes in the progressive movement people think [...] unions have this enormous pot of money $[\ldots]$ but they don't if you look at it in the grand scheme of things [...] If the coop goes under, what does that mean? And how do your members feel about that?

Citing UFCW's losses after the Philadelphia O\&O worker cooperative supermarket went bankrupt in the 1980s, Vera maintained that USW-Mondragon initiatives should have modest expectations for direct union financing due to member priorities and competing demands.

Whereas direct union financing of CUCI startups has been limited, in-kind resources such as meeting space, printing, and staff time have significantly reduced incubation costs. The single largest contribution has been UFCW's dedication of a percentage of Local 75 Field Organizer 
Ellen Vera's time to Our Harvest and Apple Street Market. She said this arrangement speaks to the potential for worker cooperative development to align with unions' larger goal of increasing membership if they can see union co-ops as a tactical alternative to plant-by-plant organizing. CUCI's challenge has been that start-ups build membership gradually over time but its union partners seem most interested in organizing strategies that yield immediate gains.

Union co-op advocates also claim that unions can enhance the legitimacy and visibility of democratic worker ownership by familiarizing their members with the idea (Crowell 2010). The U.S. has approximately 2,230 union members for every worker-owner. ${ }^{6}$ Even if unions only shared the idea with a small group of members, perhaps unions could help them begin to see worker cooperatives as a viable alternative? Several interviewees embraced this aspiration. "I think the potential is enormous in terms of just how many people [unions] are connected to, how many skilled workers we are connected to, just the fact that we are a network that's across the entire country," said Ellen Vera. She cited UFCW organizers who have become 'evangelists' for the USW-Mondragon model. Others pointed to unions that have endorsed the vision at national conventions like the United Electrical, Radio, and Machine Workers of America (UE) and AFLCIO. Several interviewees described increasing the number of union members familiar with the idea of democratic worker ownership as especially promising in the context of conversions. The U.S. will see a wave of retiring baby boomer business owners in the next decade. Many are viable firms that already employ more than 50 unionized workers. Since union stewards are often on the scene early in the succession process, interviewees described family businesses as opportunities to quickly establish large union co-ops.

Another ostensible benefit of directly involving unions in the worker cooperative formation process is access to union training and educational resources. Several interviewees

\footnotetext{
${ }^{6}$ Author's calculation based on Palmer (2015) and BLS (2014a).
} 
maintained that apprenticeship programs have significantly reduced training costs and served an important signaling function for hiring decisions at CUCI. As Sustainergy board member Nick Dill explained, “The Building Trades [...] all have apprenticeship programs and so we know the skill level of somebody based on their title [and] standing." Others described the potential for labor schools, summer institutes, and labor studies programs to develop curricula that cultivate the technical and 'soft' skills necessary for democratic worker ownership, although they had yet to realize these aspirations in Cincinnati.

Finally, advocates claim that unions can leverage their political capital to lobby for worker cooperative-friendly policies. Unions have been active in CUCI's inter-organizational network, encouraging other potential supporters to view CUCI's efforts through a labor movement frame. For example, the Building Trades Unions helped Sustainergy secure passage of PACE legislation and CUCI champions in the local labor movement have informally facilitated meetings with elected officials. Overall, accounts of CUCI informants described union partners as crucial sources of in-kind subsidies, training, legitimacy, visibility, political capital, and other resources in the worker cooperative development process.

The second possibility is for early unionization to strengthen solidarity and manage conflict between managers and rank-and-file workers. Communication and informal problem solving are crucial for developing the willingness to sacrifice for the collective good at the heart of healthy worker cooperatives (Gherardi and Masiero 1990). Sustaining solidarity can become more difficult, however, as growth increases distance between workers and management and attenuates the representative relationship between worker-owners and the board. Advocates of the USW-Mondragon model often cite the 1974 strike at Mondragon's Ulgor cooperative, when over 400 workers walked out after leadership ignored their complaints about a new job 
evaluation program, to argue that formal dispute resolution procedures must be in place early on (Whyte and Whyte 1991, 98). They claim that unionization during the formation stage not only preempts these kinds of problems but also provides grievance mechanisms to protect the rights of individual workers in the event of discrimination or unfair treatment (Huertas-Noble 2016). The CBA ostensibly helps workers hold management accountable on a day-to-day basis, ensure fair treatment, and provide due process - even for non-owners.

Several interviewees described their aspiration for the union committee to foster democratic debate and channel conflict productively throughout the life of a worker cooperative. Apple Street Market Project Manager Casey Whitten-Amadon said he believes unionization is crucial in startups because size is not a good predictor of democratic representation:

I don't think there's any magic number [i.e. threshold for unionization]. You may have a 400 person cooperative where the board of directors is totally full of solidarity $[\ldots]$ but you could also have a cooperative of 20 people where the board of directors [...] may not have that kind of consciousness.

David Ellerman calls this as the "legitimate opposition" role of a union in a worker cooperative. He argues that "an independent power-base for those who seek to express opinions and policies at variance with the powers that be" is a prerequisite for workplace democracy $(1988,48)$.

Interviewees also described their appreciation for union intervention in a conflict between a non-owner worker and management at Our Harvest in 2014. The cooperative had not yet established the institutional infrastructure to resolve the disagreement informally, and UFCW Local 75 brought its expertise with formal dispute resolution to bear after the worker filed a grievance. As Our Harvest board member Eileen Frechette said, "Although the formality of the union process for settling a grievance appeared cold at times, I think it was the clear, objective 
procedure that made resolution possible." Official union procedures felt somewhat at odds with ideals of a cooperative culture, but the benefits of union involvement outweighed the costs.

The third possibility is for unions to build solidarity across workers' movements by linking cooperative worker-owners with other working class struggles. Rob Witherell, a USW representative who helped initiate the collaboration with Mondragon, described democratic worker ownership as part of his union's efforts to promote ownership as a central dimension of worker power (Witherell 2013). Carmen Huertas-Noble, a USW-Mondragon model advocate who co-founded 1 Worker1Vote, claimed that unions "can help create and/or bolster solidarity and integrate worker-owned cooperatives into the larger economic justice movement" (2016).

CUCI founder Phil Amadon described this idea using the metaphor of a lifeboat. His diagnosis for the failure of worker cooperatives to scale in the U.S. was that they have become disconnected from the working class as a whole: "Worker co-ops by themselves have proven by their smallness, by their incredible isolation, and failure [...] to be a long term answer." In a typical worker cooperative, Amadon said, worker-owners attempt to build their own lifeboat - an isolated democratic workplace carved out in the niches of capitalism - to escape the global "race to the bottom in terms of wages, benefits, lifestyle, income" and "insulate [worker-owners] from the blows and disastrous conditions that have afflicted the majority of the working class." Since worker co-ops operate on such a small scale, however, these lifeboats only have room for "a fepeople." Amadon described the potential of the union co-op model in terms of its ability to build bridges between organized labor and the cooperative movement, thus eroding rather than escaping capitalism (Wright 2015):

The union co-op model is saying that the unions at this time on a global scale are the largest working-class organizations involved in the defense of the standard of living of working 
people $[\ldots]$ Now that we're adding organized labor into the mix $[\ldots]$ our focus becomes not just our workplace, not just our cooperative [...] but all workers everywhere.

Concretely, interviewees aspired for union co-ops to strengthen solidarity across movements by leveraging the collective power of union members and worker-owners to lobby for worker rights policies, coordinate grassroots organizing and education efforts, engage in multi-union bargaining, and extend worker control over production. As Whitten-Amadon said: We don't want to become a cooperative that is this isolated bubble that treats its employees well and has good pay and good benefits but is divorced from the rest of the struggle. We want our cooperatives to be part and parcel with the larger movement for employee rights, employee voice in the workplace, good pay, and good benefits.

CUCI has initially pursued these goals by highlighting the shared history of unions and worker cooperatives to help people reimagine the role of unions in the workplace and draw explicit connections between the movements. "What Our Harvest is doing is opening doors to people," said Our Harvest worker-owner Zeke Coleman. "[We're] allowing them to expand their thought process [about] how a job should be [and] how you should be treated at work." Some interviewees reported that workers with prior union experience grasp the interconnections more easily. "Workers that are part of a union [...] have a better understanding of what solidarity means," said Flequer Vera. "People know each other." Central to possibilities for union co-ops to foster working class solidarity is thinking beyond one's own individual cooperative.

Accounts of CUCI informants emphasized their aspirations for unionization to increase resources for worker cooperative formation, facilitate conflict resolution, and link cooperatives with the broader workers' movement. Overall, they attributed CUCI's modest progress towards realizing these aspirations to the USW-Mondragon union co-op model. They cited access to 
union-sponsored resources, conflict resolution procedures, and connections to workers' movements. Detractors have also raised a series of claims in tandem with these possibilities. Dilemmas: Antagonism, Conflict of Interest, and Discrimination

The first dilemma of direct union involvement in the worker cooperative formation process is the potential for collective bargaining to introduce antagonism into an inchoate democratic workplace. Worker-owners in successful cooperatives have a strong orientation toward collective action and egalitarian distribution (Malleson 2014, Hoffmann 2005). Yet individuals do face tradeoffs between their immediate interests and the long-term well being of their firms. Empirical studies have shown that worker cooperatives are more likely to resolve these dilemmas through informal problem solving, trust, and collective sacrifice than conventional firms (Hoffmann 2001). In contrast, the traditional trade union model of collective bargaining takes an antagonistic posture that assumes tradeoffs between worker and owner interests are zero sum. Formal labor-management programs to convince "workers to identify with the economic plight $[. .$.$] of the company" have more often led to worker concessions rather$ than collaborative improvements in working conditions and job security (Moody 2007, 10).

Skeptics of the USW-Mondragon model claim that a focus on extrinsic incentives such as wages, work hours, and benefits during collective bargaining puts worker and owner interests at odds and crowds out intrinsic incentives to resolve conflicts cooperatively (Seda-Irizarry 2011). The model envisions the union committee representing the interests of worker-owners as workers and the board of directors representing their interests as owners (Witherell, Cooper, and Peck 2012). As Ellerman has argued, however, these interests cannot be separated. The "two hats" model of traditional collective bargaining oversimplifies the complex set of worker-owner interests in a cooperative and utterly fails to "rethink the union's role" $(1988,439)$. 
Discussions over voluntary wage cuts at Our Harvest exemplify how this dilemma has manifest at CUCI. In 2014, several employees and people on track to worker ownership proposed voluntary wage cuts to reduce labor costs when sales projections fell short. They argued that the proposal was reasonable because it would increase cash flow flexibility. Minimum wage rate stipulations in the UFCW contract, however, meant that certain workers could not accept significantly less pay without violating the CBA. After an extended debate, the incubation board approved voluntary wage cuts in August 2014. In reflecting on the situation, several interviewees said that unions better serve their members by seeing the interests of workers and owners as one in the same rather than strictly adhering to the CBA. In other words, they acknowledged that collective bargaining can create distinctions between the interests of workers and owners but described it as a surmountable challenge in a union co-op.

A related claim is that the risk of introducing antagonism via collective bargaining is particularly acute in a small worker cooperative with relatively little management hierarchy. Mondragon claims that worker-owners best solve problems informally until cooperatives grow to 50 workers (Fernandez de Landa 2013), yet the USW-Mondragon model calls for introducing collective bargaining well before this threshold. CUCI's union co-ops remain very small to date. Nevertheless, several interviewees disputed the idea that unionization necessarily crowds out all intrinsic incentives and trust. As Coleman said, "The best thing about Our Harvest is the family connection that I feel we have out there.” They maintained that unionization has promoted worker-management solidarity more than CBA negotiations have undermined it.

The second dilemma is the potential for direct union involvement in business development to undermine cooperative autonomy. Trade unions tend to centralize decisionmaking because their power rests in a credible threat of noncompliance (strikes, etc.). In 
contrast, worker cooperatives tend to place a higher value on autonomy and decentralized governance. Skeptics claim that worker-owners may resist being restricted in their decisionmaking by factors external to the organization such as pressure to conform to an industry-wide master contract (Bell 2006). Union intervention may also pose a larger perceived threat to cooperative autonomy in certain areas, such as human resource management, than others.

It is common for external stakeholders like nonprofit incubators to appoint cooperative managers or board directors during the startup phase to offset initial labor costs and protect their investment. For instance, CUCI maintains one board seat and a 'golden veto' after its union coops leave the incubation stage to prevent worker owners from demutualizing after their firm becomes profitable. None of the interviewees described board appointment procedures as problematic for the autonomy of CUCI-incubated union co-ops. CUCI has determined, however, that union-sponsored managers have the potential to introduce a conflict of interest between the union's mandate to serve workers and imperatives to establish a profitable business. This lesson came about through trial and error during Ellen Vera's service as Lead Organizer of Our Harvest with backing from UFCW. CUCI realized that a union-appointed manager might find themselves in the difficult position of being expected to both discipline workers and address worker grievances about disciplinary action. As Vera said:

[The union] can be extremely involved in leading the whole process, getting the co-op to the point where it's ready to actually launch and start working. But at that point, that's where the role of the union is to represent the workers from a worker point of view and to not be part of actually managing the co-op itself.

Overall, interviewees described in-kind contributions of union staff as instrumental during the early phases of incubation - with the caveat that they are limited to non-management roles. 
Schlachter 26

The final dilemma of unionization is related to the risk of introducing discriminatory practices that are antithetical to a cooperative culture. A legacy of corporate-bureaucratic union practices combined with the historic prevalence of skilled, white, male leaders has led some skeptics to question if unions are a good fit for a rapidly diversifying worker cooperative sector (Seda-Irizarry 2011). U.S. unions now formally embrace of civil and women's rights, but some critics of the USW-Mondragon template claim that their legacy of exclusion will make marginalized workers feel less welcome in a unionized worker cooperative.

Several CUCI interviewees described CUCI's organizational culture as much more akin to a diverse, grassroots social movement than business unionism. The national union co-op movement leadership is primarily made up of activists within the union movement rather than traditional trade unions; this is also the case at CUCI (1Worker1Vote 2016). "I would say this is not really 'The Unions' capitalized," said Whitten-Amadon. "This is a bunch of union people who happen to be somewhat involved in the union movement." Workers at Our Harvest and Sustainergy maintained that early unionization has enriched the development of a welcoming work environment. As Coleman said:

I would say this is probably the best job I've ever had in my whole life. I'm never worried about having a target on my back because of my skin color [...] I've never been treated as equal as I've been treated here - than I've ever been treated in my whole entire life. In short, interviewees described the claim that unionization introduces discriminatory practices into a worker cooperative as irrelevant to their early experiences.

\section{Discussion and Conclusion}

As the first initiative to implement the USW-Mondragon model, I argue that CUCI offers valuable considerations for the ongoing debate about whether unions and worker cooperatives 
can be stronger together. Table IV summarizes key possibilities and dilemmas of direct union involvement in the worker cooperative formation process.

Table IV: Possibilities and Dilemmas of Direct Union Involvement in the Worker Cooperative Formation Process as Envisioned by the USW-Mondragon Model

Scholars and cooperative developers can draw from a rich set of aspirations and experiences at CUCI as they explore these possibilities and dilemmas in future research and union co-op initiatives in other contexts. For example, interviewees described access to union resources like staff time and training as a key benefit of the USW-Mondragon model. Credit constraints remain an ongoing challenge, however, and unions have been reluctant to invest directly in risky startup ventures. Future research should explore whether unions would be more amenable to investing in established firms that use employee stock ownership plans as a bridge to democratic worker ownership (Blasi and Kruse 2012). Interviewees also highlighted the possibilities of early unionization as a preemptive measure to foster solidarity and protect individual rights through formal procedures. UFCW representation at Our Harvest codified expectations in a CBA and helped the business navigate a challenging grievance process. Finally, CUCI informants embraced the possibility for unionization to link worker cooperatives with broader workers' movements. They described unionization as a way to encourage workerowners to think beyond their own firm.

CUCI's responses to skeptical claims about the USW-Mondragon model can also help structure the debate going forward. For instance, informants acknowledged the dilemma that collective bargaining can separate the interests of workers and owners and heighten focus on extrinsic incentives. Yet they described these as manageable challenges, citing voluntary wage cuts at Our Harvest as evidence that worker-owners can successfully navigate tradeoffs between 
compensation guarantees and wage flexibility that affect long-term viability. Interviewees described dilemmas related to preserving worker cooperative autonomy as more pressing, necessitating limits to direct union involvement in day-to-day operations. Although they said inkind contributions of union staff time were instrumental during the early phases of incubation, they described these contributions as best limited to non-management roles. Finally, CUCI informants disputed claims that union co-ops are necessarily less welcoming to marginalized groups. An outstanding question is whether union co-ops continue to be diverse and welcoming spaces after grassroots activists no longer lead them.

As the USW-Mondragon model debate unfolds, future research should examine CUCI alongside cases in other contexts and avoid generalizing its early experiences too broadly. CUCI launched in 2011 during a period of economic and social change. Cincinnati's recovery from the Great Recession continues to lag behind peer cities and the statewide labor movement has faced ongoing challenges after Ohio voters narrowly rejected restrictions on public sector unions in 2011(Brookings Institute 2014). Recent racially charged police violence has underscored profound levels of segregation and inequality in the city. These challenges motivated CUCI's founders yet complicated their early attempts to get startups off the ground. For these reasons, my goal in this article has not been to validate claims about the USW-Mondragon model but to put them in dialogue with the aspirations and experiences of its earliest adopters.

A key limitation of my synthesis of possibilities and dilemmas has been the focus on implications of union involvement for worker cooperatives, which is only one side of the story. From the perspective of many union co-op advocates, the USW-Mondragon model represents a strategy to counteract union decline. For example, they have argued that democratic worker ownership would allow unions to rediscover their emancipatory potential, gain new members, 
expand their capacity for grassroots organizing, and make them more relevant to workers seeking transformative changes in the economy (Hoyer 2015). Future research on what worker cooperatives bring to unions would enrich our understanding of their promise and potential.

Despite the emancipatory aspirations of worker cooperatives, their marginality in the U.S. economy requires creative solutions to the ways in which they fall short. This article is an invitation to think through implications of the USW-Mondragon union co-op model in a theoretically- and empirically-grounded way. I have argued that the model invokes possibilities for unionization to address constraints in the worker cooperative formation process through increased resources, conflict resolution, and solidarity across movements. It also invokes dilemmas related to antagonism, cooperative autonomy, and discrimination. My case study of CUCI is the first attempt to ground the aspirations and experiences of union co-ops empirically in an emerging USW-Mondragon initiative. Although there is much to learn as CUCI's efforts play out in real time, it offers an illuminating glimpse into one attempt to prefigure an economy that works for all. 
Table I: Union Co-op Initiatives in the Mondragon USA Network, August 2016

\begin{tabular}{|c|c|c|c|c|}
\hline City & Incubator & $\begin{array}{l}\text { Union Co-op(s) } \\
\text { Launched to Date }\end{array}$ & $\begin{array}{l}\text { New Ideas in } \\
\text { Development }\end{array}$ & Affiliated Union(s) \\
\hline Bronx, NY & ICA Group & 0 & Residential Moving & USW \\
\hline Buffalo, NY & $\begin{array}{l}\text { Cooperation } \\
\text { Buffalo }\end{array}$ & 0 & Energy & to be determined \\
\hline Chicago, IL & Working World & $\begin{array}{l}\text { New Era Windows } \\
\text { and Doors (2013) }\end{array}$ & to be determined & UE \\
\hline Cincinnati, $\mathrm{OH}$ & $\begin{array}{c}\text { Cincinnati Union } \\
\text { Co-op Initiative }\end{array}$ & \begin{tabular}{|c|} 
Our Harvest Food \\
Hub \& Farm (2012); \\
Sustainergy Energy \\
Retrofitting (2013)
\end{tabular} & $\begin{array}{l}\text { Apple Street Market } \\
\text { Retail Grocery; } \\
\text { Sarah Center } \\
\text { Jewelry } \\
\end{array}$ & UFCW \& Insulators \\
\hline Denver, CO & $\begin{array}{l}\text { Rocky Mountain } \\
\text { Employee } \\
\text { Ownership Center }\end{array}$ & Green Taxi (2014) & Day Laborers & CWA \\
\hline Los Angeles, CA & $\begin{array}{l}\text { Los Angeles Eco- } \\
\text { Village }\end{array}$ & $\begin{array}{l}\text { Pacific Electric } \\
\text { (2014) }\end{array}$ & Car Wash & IBEW \& USW \\
\hline Las Vegas, NV & $\begin{array}{c}\text { Las Vegas Worker } \\
\text { Ownership } \\
\text { Resources and } \\
\text { Cooperative } \\
\text { Services } \\
\end{array}$ & 0 & Farmers Market & to be determined \\
\hline Pittsburgh, PA & $\begin{array}{l}\text { Steel Valley } \\
\text { Authority }\end{array}$ & 0 & $\begin{array}{c}\text { Clean and Green } \\
\text { Laundry }\end{array}$ & USW \\
\hline Reading, PA & City of Reading & 0 & $\begin{array}{l}\text { Home Health Care, } \\
\text { Recycling, } \\
\text { Weatherization }\end{array}$ & $\begin{array}{l}\text { USW \& Laborer's } \\
\text { Union }\end{array}$ \\
\hline $\begin{array}{l}\text { San Francisco- } \\
\text { Oakland, CA }\end{array}$ & $\begin{array}{c}\text { Bay Area } \\
\text { Blueprint } \\
\text { Collaborative }\end{array}$ & 0 & to be determined & to be determined \\
\hline St. Louis, MO & $\begin{array}{l}\text { Culver Way } \\
\text { Ecovillage }\end{array}$ & 0 & Food Hub & to be determined \\
\hline
\end{tabular}


Schlachter 31

Table II: Worker Cooperative Typology

\begin{tabular}{|c|c|c|}
\hline Type of Firm & Unionized & $\begin{array}{c}\text { Moment of } \\
\text { Unionization }\end{array}$ \\
\hline Worker Cooperative & No & $\mathrm{n} / \mathrm{a}$ \\
\hline Unionized Worker Cooperative & Yes & After Founding \\
\hline USW-Mondragon Union Co-op & Yes & At Founding \\
\hline
\end{tabular}

Stronger Together? The USW-Mondragon Union Co-op Model 
Table III: CUCI Union Co-ops, August 2016

\begin{tabular}{|c|c|c|c|c|c|}
\hline Union Co-op & Description & Status & $\begin{array}{c}\text { Managers and } \\
\text { Employees }\end{array}$ & Worker Owners & Union Affiliation \\
\hline Our Harvest & $\begin{array}{l}\text { Food hub and } \\
\text { urban farm }\end{array}$ & $\begin{array}{c}\text { Launched April } \\
\text { 2012; inaugural } \\
\text { general assembly } \\
\text { fall } 2015\end{array}$ & 18 & 4 & UFCW Local 75 \\
\hline Sustainergy & $\begin{array}{c}\text { Residential } \\
\text { energy retrofits }\end{array}$ & $\begin{array}{l}\text { Launched } \\
\text { November 2013; } \\
\text { re-launched } \\
\text { March 2015 }\end{array}$ & 4 & 1 & Insulators Local 8 \\
\hline $\begin{array}{l}\text { Apple Street } \\
\text { Market }\end{array}$ & $\begin{array}{l}\text { Multi-stakeholder } \\
\text { retail grocery in } \\
\text { food desert }\end{array}$ & $\begin{array}{c}\text { Hired General } \\
\text { Manager in } 2015 ; \\
1,129 \text { consumer } \\
\text { members; launch } \\
\text { projected } 2017\end{array}$ & 1 & 0 & UFCW Local 75 \\
\hline $\begin{array}{l}\text { Sarah Center } \\
\text { Jewelry } \\
\text { Cooperative }\end{array}$ & $\begin{array}{l}\text { Produce and retail } \\
\text { handmade jewelry }\end{array}$ & $\begin{array}{l}\text { Feasibility study } \\
\text { complete but } \\
\text { project on hold } \\
\text { pending funding }\end{array}$ & 0 & 0 & USW District 3 \\
\hline $\begin{array}{l}\text { Danobat Group } \\
\text { Railway Division }\end{array}$ & $\begin{array}{l}\text { US-based branch } \\
\text { of Mondragon } \\
\text { railcar part plant }\end{array}$ & $\begin{array}{c}\text { Discontinued in } \\
\text { July } 2014 \text { after } \\
\text { Danobat decided } \\
\text { to pursue oil \& } \\
\text { gas project in } \\
\text { Texas }\end{array}$ & $\mathrm{n} / \mathrm{a}$ & $\mathrm{n} / \mathrm{a}$ & USW \\
\hline Yucky Cookies & $\begin{array}{c}\text { Bake and } \\
\text { distribute healthy } \\
\text { cookies }\end{array}$ & $\begin{array}{l}\text { Discontinued in } \\
\text { June } 2015 \text { after } \\
\text { mother-son team } \\
\text { decided not to } \\
\text { pursue conversion }\end{array}$ & $\mathrm{n} / \mathrm{a}$ & $\mathrm{n} / \mathrm{a}$ & UFCW \\
\hline
\end{tabular}


Table IV: Possibilities and Dilemmas of Direct Union Involvement in the Worker Cooperative Formation Process as Envisioned by the USW-Mondragon Model

Possibilities

Unions address key barriers to scale for worker cooperatives by bringing resources to bear in the formation process.

Early unionization strengthens solidarity and manages conflict between managers and rank-and-file workers

Unions build solidarity across workers' movements by linking cooperative worker-owners with other working class struggles.

Dilemmas

Collective bargaining introduces antagonism into an inchoate democratic workplace.

Direct union involvement in business development undermines cooperative autonomy.

Unions introduce discriminatory practices that are antithetical to a cooperative culture. 


\section{BIBLIOGRAPHY}

1Worker1Vote. 2016. "Co-Founders." Accessed September 9. http://1worker1vote.org/about/cofounders/.

Abell, Hilary. 2014. Worker Cooperatives: Pathways to Scale. Takoma Park, MD: The Democracy Collaborative.

Bartlett, Will, John Cable, Saul Estrin, Derek Jones, and Stephen Smith. 1992. "Labor-Managed Cooperatives and Private Firms in North Central Italy: An Empirical Comparison." Industrial and Labor Relations Review 46 (1):103-118.

Bell, Dan. 2006. "Cooperatives and Unions: Why Can’t We Just Get Along?" The Co-Operative And Its Workers, A Symposium, Saint Mary's University, Halifax, Nova Scotia, June 1517.

Berry, Daphne Perkins, and Stu Schneider. 2011. "Improving the Quality of Home Health Aide Jobs: A Collaboration between Organized Labor and a Worker Cooperative." In Employee Ownership and Shared Capitalism: New Directions in Research, edited by Edward J. Carberry, 59-89. Labor and Employment Relations Association Series. Ithaca and London: Cornell University Press, ILR Press.

Blasi, Joseph, and Douglas Kruse. 2012. "Broad-based Worker Ownership and Profit Sharing: Can These Ideas Work in the Entire Economy?" Working Paper:1-32.

BLS, Bureau of Labor Statistics. 2014a. "Business Employment Dynamics: Entrepreneurship and the U.S. Economy." http://www.bls.gov/bdm/entrepreneurship/bdm chart3.htm.

BLS, Bureau of Labor Statistics. 2014b. "Economic News Release: Union Members Summary." Last Modified January 24 Accessed January 22. http://www.bls.gov/news.release/union2.nr0.htm.

BLS, Bureau of Labor Statistics. 2015. "Union Members - 2014." Bureau of Labor Statistics Accessed September 7.

Bonin, John, Derek Jones, and Louis Putterman. 1993. "Theoretical and Empirical Studies of Producer Cooperatives: Will Ever the Twain Meet?" Journal of Economic Literature 31 (3):1290-1320.

Brookings Institute. 2014. "Global Metro Monitor Map." Brookings Institute Accessed September 7.

CensusScope. 2015. "Segregation: Dissimilarity Indices." CensusScope Accessed September 1, 2015. http://www.censusscope.org/us/rank_dissimilarity white black.html.

Corcoran, Hazel, and David Wilson. 2010. The Worker Co-operative Movements in Italy, Mondragon, and France: Context, Success Factors, and Lessons. Calgary, AB, Canada: Canadian Worker Co-operative Federation.

Crowell, Erbin. 2010. "Mondragon and the United Steelworkers: New opportunity for the co-op and labor movements?" Cooperative Grocer, 8-9.

CUCI, The Cincinnati Union Co-op Initiative. 2014. Annual Report. Cincinnati, OH: The Cincinnati Union Co-op Initiative.

Curnutte, Mark. 2013. "City's child-poverty rate one of the worst in the US." The Cincinnati Enquirer, September 19.

DAWI, Democracy at Work Institute. 2016. "New York City Continues to Pioneer Innovative Economic Development Strategies." June 26. http://institute.coop/news/new-york-citycontinues-pioneer-innovative-economic-development-strategies-committing-another. 
Dean, Amy. 2013. "Why Unions Are Going Into the Co-op Business: The Steelworkers deal that could turn the Rust Belt green." Yes!, 26-28.

Deller, Steven, Ann Hoyt, Brent Hueth, and Reka Sundaram-Stukel. 2009. "Research on the Economic Impact of Cooperatives." Madison, WI: University of Wisconsin Center for Cooperatives.

Ellerman, David. 1988. "The Legitimate Opposition at Work: the Union's Role in Large Democratic Firms." In Economic and Industrial Democracy, 437-453. London, Newbury Park, Beverly Hills, and New Delhi: SAGE.

Fernandez de Landa, Fernando. 2013. "Delving into Mondragon's Structure, Experience, Best Practices, Key Learnings." Union Co-op Symposium, Cincinnati, OH, December 9.

Gherardi, Silvia, and Attilio Masiero. 1990. "Solidarity as a Networking Skil and a Trust Relation: Its Implications for Cooperative Development." Economic and Industrial Democracy 11 (November):553-574.

Gintis, Herbert. 1998. "Summary of Financial Markets and the Political Structure of the Enterprise." In The Changing Nature of Work, edited by Frank Ackerman, Neva Goodwin, Laurie Dougherty and Kevin Gallagher, 255-258. New York: Island Press.

Gordon Nembhard, Jessica. 2014. Collective Courage: A History of African American Cooperative Economic Thought and Practice. University Park: Pennsylvania State University Press.

Gordon Nembhard, Jessica, and Anthony Blasingame. 2006. "Wealth, Civic Engagement, and Democratic Practice." In Wealth Accumulation in Communities of Color in the United States: Current Issues, edited by Jessica Gordon Nembhard and Ngina Chiteji, 294-325. Ann Arbor, MI: University of Michigan Press.

Greenberg, Edward. 1986. Workplace Democracy: The Political Effects of Participation. Ithaca, NY: Cornell University Press.

Hansmann, Henry. 1996. The Ownership of Enterprise. Cambridge, MA: Harvard University Press.

Hirsch, Barry, and David Macpherson. 2014. Union Membership, Coverage, Density, and Employment by Metropolitan Area and Sector, 1986-2014. In Union Membership and Coverage Database from the CPS, edited by Barry Hirsch and David Macpherson. Online.

Hoffmann, Elizabeth. 2001. "Confrontations and Compromise: Dispute Resolution at a Worker Cooperative Coal Mine." Law \& Social Inquiry 26 (3):555-596.

Hoffmann, Elizabeth. 2005. "Dispute Resolution in a Worker Cooperative: Formal Procedures and Procedural Justice." Law \& Society Review 39 (1):51-82.

Hoffmann, Elizabeth. 2006a. "Driving Street Justice: The Taxicab Driver as the Last American Cowboy." Labor Studies Journal 31 (2):31-48.

Hoffmann, Elizabeth. 2006b. "Exit and Voice: Organizational Loyalty and Dispute Resolution Strategies." Social Forces 84 (4):2313-2330.

Hoyer, Mary. 2015. "Title." Grassroots Economic Organizing (GEO), 2015. http://geo.coop/story/labor-unions-and-worker-co-ops.

Huertas-Noble, Carmen. 2016. "Worker-Owned and Unionized Worker-Owned Cooperatives: Two Tools to Address Income Inequality." Clinical Law Review 22 (2):325-358.

Jilani, Zaid. 2015. Bernie Sanders' Campaign Issues Truly Extradordinary Campaign Plank. Alternet. Accessed May 5, 2015. 
Kelly, Marjorie. 2012. Owning Our Future: The Emerging Ownership Revolution. San Francisco: Berrett-Koehler Publishers, Inc.

Loh, Penn, and Boone Shear. 2015. "Solidarity economy and community development: emerging cases in three Massachusetts cities." Community Development 46 (3):244-260.

Majee, Wilson, and Ann Hoyt. 2010. "Are worker-owned cooperatives the brewing pots for social capital?" Community Development 41 (4):417-430.

Malleson, Tom. 2014. After Occupy: Economic Democracy for the 21st Century. New York: Oxford University Press.

Michael, Christopher. 2015. "Worker Cooperative Development Strategies." Grassroots Economic Organizing (GEO), July 2015. http://geo.coop/story/what-worker-cooperativedevelopment.

Moody, Kim. 2007. U.S. Labor in Trouble and Transition: The Failure of Reform From Above, The Promise of Revival From Below. London: Verso.

Navarro, Vincent. 2014. The Case of Mondragon. edited by Counter Punch: Counter Punch.

NEC, New Economy Coalition. 2015. "Home." Accessed August 4. http://neweconomy.net/.

Olsen, Erik K. 2013. "The Relative Survival of Worker Cooperatives and Barriers to Their Creation." Advances in the Economic Analysis of Participatory \& Labor-Managed Firms 14 (Sharing Ownership, Profits, and Decision-making in the 21st Century):83-107.

Palmer, Tim. 2015. U.S. Worker Cooperatives: A State of the Sector. In Research Publication Series: The Democracy at Work Institute.

Putnam, Robert. 1993. Making Democracy Work: Civic Traditions in Modern Italy. Princeton, NJ: Princeton University Press.

Reedy, E.J., and Robert E. Litan. 2011. Stating Smaller; Staying Smaller: America's Slow Leak in Job Creation. In Kauffman Foundation Research Series: Firm Formation and Economic Growth, edited by Kaufman Foundation. Kansas City, MO: Ewing Marion Kauffman Foundation.

Schlachter, Laura Hanson. 2016. City of Madison Grant Writing Process. In MCDC Milestone Reflections Series. Madison, WI: University of Wisconsin Center for Cooperatives.

Seda-Irizarry, Ian. 2011. "Crisis, Class, and Cooperatives: Some Comments on the United Steelworkers-Mondragon Alliance." Rethinking Marxism: A Journal of Economics, Culture and Society 23 (3):374-383.

Sherlock, Meghan. 2014. "Title." MBAx, August 13. http://mbaxamerica.com/team-harvardbringing-fresh-produce-to-local-food-deserts-our-harvest-and-the-urban-farm/.

Silver, Nate. 2012. The Signal and the Noise: Why So Many Predictions Fail - but Some Don't. New York, NY: Penguin Books.

UCC, USFWC Union Co-ops Council. 2016. "Union Co-ops Council of the US Federation of Worker Cooperatives." Accessed September 9. http://unioncoops.org/.

USW, The United Steelworkers. 2013. "USW Co-ops: Resources and Updates." Accessed October 1. http://usw.org/our_union/co-ops.

USW, United Steelworkers Union, and Mondragon Cooperative Corporation MCC. 2009. Framework Agreement Between The United Steelworkers (USW) and Mondragon Internacional, S.A.

Whyte, William Foote, and Kathleen King Whyte. 1991. Making Mondragon. Ithaca, NY: Cornell University Press. 
Witherell, Rob. 2013. "An Emerging Solidarity: Worker Cooperatives, Unions, and the New Union Co-op Model in the United States." International Journal of Labour Research 5 (2):251-268.

Witherell, Rob, Chris Cooper, and Michael Peck. 2012. Sustainable Jobs, Sustainable Communities: The Union Co-op Model.

Wright, Erik Olin. 2010. Envisioning Real Utopias. London and New York: Verso.

Wright, Erik Olin. 2012. "Transforming Capitalism Through Real Utopias." American Sociological Review XX (X):1-25.

Wright, Erik Olin. 2015. "Challenging (and Maybe Transcending) Capitalism Through Real Utopias." International Sociological Debates at the University of Barcelona, School of Economics and Business, University of Barcelona. 